\title{
ANALISIS KEPUASAN PELANGGAN DENGAN IMPORTANCE PERFORMANCE ANALYSIS DI SBU LABORATORY CIBITUNG PT SUCOFINDO (PERSERO)
}

\author{
Johan Oscar Ong ${ }^{1}$, Jati Pambudi ${ }^{2}$ \\ ${ }^{1)}$ Fakultas Teknik, Jurusan Teknik Industri, President University \\ Jl. Ki Hajar Dewantara Kota Jababeka, Cikarang, Bekasi - Indonesia 17550 \\ ${ }^{2)}$ SBU Laboratory Cibitung PT Sucofindo (Persero) \\ Jl. Arteri Tol Cibitung No. 1 Cibitung, Bekasi - Indonesia 17 \\ johanoscarong@gmail.com
}

\begin{abstract}
Abstrak
Kepuasan pelanggan adalah perbandingan antara kinerja yang diharapkan oleh pelanggan dibandingkan dengan kinerja aktual di lapangan. Ketika kinerja aktual lebih tinggi dibandingkan dengan harapan pelanggan maka pelanggan merasakan puas dan sebaliknya. Pada kasus perusahaan jasa, kepuasan pelanggan adalah salah satu faktor penting dalam menciptakan iklim bisnis yang baik, pada contoh kasus ini, SBU Laboratory Cibitung PT Sucofindo (Persero) belum maksimal dalam memuaskan hasrat pelanggan, untuk itu perlu dianalisis faktor apa saja yang berpengaruh. Dilihat dari kualitas pelayanan serta aplikasi bauran pemasaran yang meliputi variabel Reliability, Responsiveness, Assurance, Empathy, Tangible, Product Quality, dan Price di SBU Laboratory Cibitung PT Sucofindo (Persero) yang dianalisis melalui Importance Performance Analysis (IPA) maka dari tiga puluh lima atribut yang termasuk pada tujuh variabel tersebut maka ada dua hal penting yang perlu di improvisasi yaitu mengenai atribut biaya jasa yang ditawarkan PT Sucofindo harus sesuai dengan kualitas dan paket harga yang ditawarkan agar terjangkau/menarik, sedangkan dari analisis gap antara kinerja aktual dan harapan maka dapat diketahui bahwa kinerja SBU Laboratory Cibitung PT Sucofindo (Persero) belum ada yang melampaui harapan pelanggan.
\end{abstract}

Kata Kunci : kualitas pelayanan, aplikasi bauran pemasaran, importance performance analysis (IPA), kepuasan pelanggan

\begin{abstract}
Customer satisfaction is comparison between customer's expected performance and actual performance. When actual performance is higher than customer expectation, customer will be satisfied and vice versa. Case at service companies, customer satisfaction is one of the important factor in creating good climate for business, in this case study, SBU Laboratory Cibitung PT Sucofindo (Persero) has not maximized in serving customer needs. Therefore, it needs to be analyzed the factors affecting that matter. From the quality service and the application of marketing mix, consist of Reliability, Responsiveness, Assurance, Empathy, Tangible, Product Quality, and Price Reliability, Responsiveness, Assurance, Empathy, Tangible, Product Quality, and Price variable at SBU Laboratory Cibitung PT Sucofindo (Persero) which have been analyzed by using Importance Performance Analysis from thirty five attributes which represent the seven variables show there are two things to be improved, they are cost of service attribute has to be adjusted to the quality and each price package has to be attainable. The gap analysis between actual performance and expectation shows that performance of SBU Laboratory Cibitung PT Sucofindo (Persero) has not surpassed customer expectations.
\end{abstract}

Keywords : service quality, marketing mix applications, importance performance analysis (IPA), customer satisfaction

\section{PENDAHULUAN}

Perdagangan bebas AFTA-China yang sudah dimulai saat ini, memaksa pemerintah sebagai pemegang regulasi untuk senantiasa mengawasi atau menginspeksi setiap masuknya produkproduk asing ke Indonesia. Dalam hal ini pemerintah sudah cukup berperan aktif dalam menghadapi kenyataan tersebut. Saat ini pemerintah sudah mempunyai gerakan 
untuk menstandarisasikan semua produkproduk yang beredar yaitu melalui Genap SNI (Gerakan Nasional Penerapan Standar Nasional Indonesia) baik untuk keperluan ekspor maupun impor, hai ini ditujukan bukan lain adalah dalam rangka melindungi konsumen agar produk yang sampai ke tangan mereka adalah produk yang layak atau terstandarisasi. Dari sanalah pemerintah menjalin kerjasama dengan lembaga atau instansi-instansi terkait baik milik pemerintah maupun swasta untuk mengawasi peredaran produk-produk dipasaran, dalam hal ini PT Sucofindo (Persero) adalah salah satu mitra pemerintah dalam pengawasan tersebut.

SBU Laboratory Cibitung PT Sucofindo (Persero) berdiri sejak 1997, bergerak di bidang jasa analisis, kalibrasi dan inspeksi. Seiring dengan perkembangan zaman, perusahaan yang bergerak di bidang yang sama dengan PT Sucofindo (Persero) sudah banyak bermunculan baik yang berasal dari dalam maupun luar negeri, hal tersebut patut diperhatikan karena bisa mengancam eksistensi dari PT Sucofindo (Persero). Untuk itulah perlu adanya peningkatan kepuasan pelanggan demi terciptanya iklim perusahaan yang baik. Dalam beberapa teori, kepuasan pelanggan dipengaruhi oleh beberapa hal, salah satunya adalah kualitas pelayanan dan bauran pemasaran. Dalam model penelitian Zeithaml (2000), kepuasan pelanggan dipengaruhi oleh variabel reliability (kehandalan), responsiveness (daya tanggap), assurance (jaminan), emphaty (empati), tangible (bukti fisik), product quality (kualitas produk), dan price (harga).

Berdasarkan data perusahaan 2011 mengenai kualitas pelayanan, maka dapat diketahui bahwa yang menonjol dari kualitas pelayanan tersebut hanyalah dari segi variabel tangible (bukti fisik), sementara fakta di lapangan masih ditemukannya jumlah komplain yang banyak, serta adanya salah satu divisi yang mengalami penuruanan order hingga $30 \%$ pada tahun 2012, yang diindikasikan adanya ketidakpuasan pelanggan mengenai harga, sehingga pelanggan tersebut beralih menggunakan jasa perusahaan lain. Dari sanalah perlu bagi perusahaan untuk meningkatkan kepuasan pelanggan tidak hanya dari kualitas pelayanan melainkan juga mengenai aplikasi bauran pemasarannya. Untuk dapat meningkatkan kepuasan pelanggan perlu pengukuran tingkat kepuasan pelanggan dengan membandingkan persepsi pelanggan dengan harapan pelanggan mengenai kinerja SBU Laboratory Cibitung PT Sucofindo (Persero). Analisis gap tersebut dilakukan terhadap campuran dari variabel kualitas pelayanan dan bauran pemasaran yang meliputi variabel reliability (kehandalan), responsiveness (daya tanggap), assurance (jaminan), emphaty (empati), tangible (bukti fisik), product quality (kualitas produk), dan price (harga). Untuk menganalisis lebih lanjut digunakan metode (Importance Performance Analysis) IPA dimana dengan menggunakan metode ini dapat melihat sejauh mana pencapaian perusahaan, serta yang perlu dipertahankan dan ditingkatkan oleh perusahaan.

\section{METODE PENELITIAN}

\section{Kepuasan Pelanggan}

Kepuasan pelanggan didefinisikan sebagai wujud perasaan konsumen setelah membandingkan dengan harapannya. Apabila kinerja perusahaan dibawah harapan konsumen maka konsumen akan kecewa dan sebaliknya sehingga dapat disimpulkan bahwa kepuasan merupakan respon dari pemenuhan kebutuhan konsumen. Menurut Zeithaml (2000) kepuasan pelanggan dipengaruhi oleh empat faktor yaitu fitur produk dan layanan, emosi konsumen, pendukung sukses maupun gagalnya pelayanan serta persepsi keadilan konsumen. Adapun model kepuasan pelanggan menurut Zeithaml (2000) adalah sebagai berikut: 


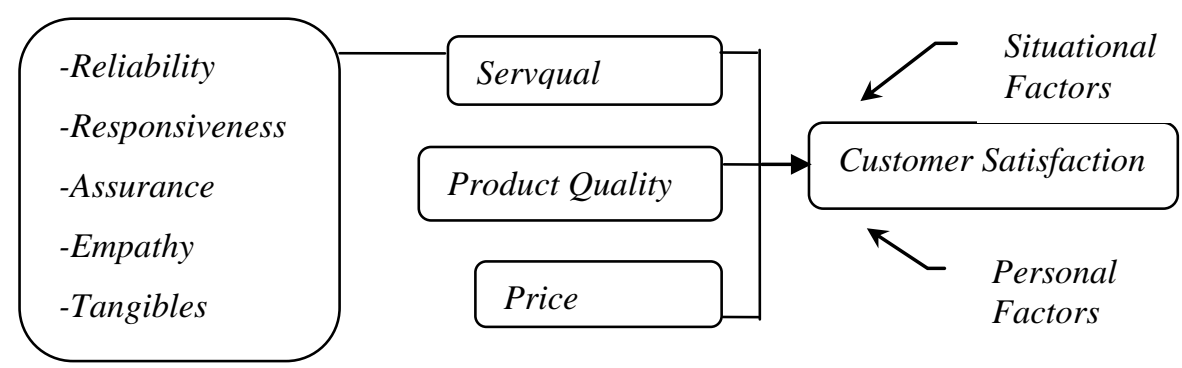

Sumber : Zeithaml dan Bitner (2000)

Gambar 1 Model Customer Satisfaction

Tabel 1 Variabel dan Atribut Penelitian

\begin{tabular}{|c|c|c|c|}
\hline No & Variabel & Atribut & Pernyataan \\
\hline \multirow[t]{5}{*}{1} & Reliability & $\begin{array}{l}\text { Menyediakan jasa sesuai yang } \\
\text { dijanjikan }\end{array}$ & $\begin{array}{l}\text { PT Sucofindo menyediakan jasa sesuai yang } \\
\text { dijanjikan }\end{array}$ \\
\hline & & $\begin{array}{l}\text { Dapat diandalkan dalam menangani } \\
\text { masalah jasa pelanggan }\end{array}$ & $\begin{array}{l}\text { Karyawan PT Sucofindo menyediakan jasa yang } \\
\text { dapat menangani masalah pelanggan }\end{array}$ \\
\hline & & $\begin{array}{l}\text { Menyampaikan jasa secara benar } \\
\text { semenjak pertama kali }\end{array}$ & $\begin{array}{l}\text { Karyawan PT Sucofindo menyampaikan jasa } \\
\text { secara benar sejak pertama kali }\end{array}$ \\
\hline & & $\begin{array}{l}\text { Menyampaikan jasa sesuai dengan } \\
\text { waktu yang dijanjikan }\end{array}$ & $\begin{array}{l}\text { PT Sucofindo menyampaikan jasa sesuai } \\
\text { deadline / waktu yang dijanjikan }\end{array}$ \\
\hline & & $\begin{array}{l}\text { Menyimpan catatan / dokumen } \\
\text { tanpa kesalahan }\end{array}$ & Sertifikat hasil analisa jelas / tanpa kesalahan \\
\hline \multirow[t]{6}{*}{2} & Responsive & Menginformasikan pelanggan & Karyawan PT Sucofindo menyampaikan \\
\hline & ness & $\begin{array}{l}\text { tentang kepastian waktu } \\
\text { penyampaian jasa }\end{array}$ & kepastian waktu deadline / penyampaian jasa \\
\hline & & $\begin{array}{l}\text { Layanan yang segera / cepat bagi } \\
\text { pelanggan }\end{array}$ & Pelayanan PT Sucofindo cepat \\
\hline & & $\begin{array}{l}\text { Kesediaan untuk membantu } \\
\text { pelanggan }\end{array}$ & PT Sucofindo bersedia membantu pelanggan \\
\hline & & Kesiapan untuk merespon & PT Sucofindo mempunyai respon yang baik \\
\hline & & permintaan pelanggan & $\begin{array}{l}\text { ketika ada permintaan pelanggan mengenai } \\
\text { kebutuhan jasa }\end{array}$ \\
\hline \multirow[t]{4}{*}{3} & Assurance & $\begin{array}{l}\text { Karyawan yang menumbuhkan rasa } \\
\text { percaya para pelanggan }\end{array}$ & $\begin{array}{l}\text { Karyawan PT Sucofindo menumbuhkan rasa } \\
\text { percaya para pelanggan }\end{array}$ \\
\hline & & $\begin{array}{l}\text { Membuat pelanggan merasa aman } \\
\text { sewaktu melakukan transaksi }\end{array}$ & $\begin{array}{l}\text { Sistem transaksi jasa PT Sucofindo berjalan } \\
\text { dengan baik }\end{array}$ \\
\hline & & $\begin{array}{l}\text { Karyawan yang secara konsisten } \\
\text { bersikap sopan }\end{array}$ & Karyawan PT Sucofindo melayani dengan baik \\
\hline & & $\begin{array}{l}\text { Karyawan yang mampu menjawab } \\
\text { pertanyaan pelanggan }\end{array}$ & $\begin{array}{l}\text { Karyawan PT Sucofindo mampu menjawab } \\
\text { pertanyaan pelanggan seputar jasa yang } \\
\text { ditawarkan }\end{array}$ \\
\hline \multirow[t]{6}{*}{4} & Empathy & $\begin{array}{l}\text { Memberikan perhatian individual } \\
\text { kepada para pelanggan }\end{array}$ & $\begin{array}{l}\text { Karyawan PT Sucofindo memberi perhatian } \\
\text { individual kepada para pelanggan }\end{array}$ \\
\hline & & $\begin{array}{l}\text { Karyawan yang memperlakukan } \\
\text { pelanggan secara penuh perhatian }\end{array}$ & $\begin{array}{l}\text { Karyawan PT Sucofindo memperlakukan } \\
\text { pelanggan dengan penuh perhatian }\end{array}$ \\
\hline & & Sungguh-sungguh mengutamakan & Karyawan PT Sucofindo mengutamakan \\
\hline & & kepentingan pelanggan & kepentingan kepentingan pelanggan \\
\hline & & $\begin{array}{l}\text { Karyawan yang memahami } \\
\text { kebutuhan nelangoan }\end{array}$ & Karyawan PT Sucofindo memahami kebutuhan \\
\hline & & Waktu beroperasi yang nyaman & $\begin{array}{l}\text { PT Sucofindo mempunyai waktu beroperasi } \\
\text { yang baik }\end{array}$ \\
\hline \multirow[t]{2}{*}{5} & Tangibles & Peralatan modern & Peralatan yang digunakan PT Sucofindo modern \\
\hline & & Fasilitas yang berdaya tarik visual & Fasilitas gedung PT Sucofindo rapi / bersih \\
\hline
\end{tabular}




\begin{tabular}{|c|c|c|c|}
\hline No & Variabel & Atribut & Pernyataan \\
\hline \multirow{8}{*}{6} & & $\begin{array}{l}\text { Karyawan yang berpenampilan rapi } \\
\text { dan professional }\end{array}$ & $\begin{array}{l}\text { Karyawan PT Sucofindo berpenampilan rapi } \\
\text { dan professional }\end{array}$ \\
\hline & & $\begin{array}{l}\text { Materi-materi berkaitan dengan jasa } \\
\text { yang berdaya tarik visual }\end{array}$ & $\begin{array}{l}\text { PT Sucofindo (Persero) mempunyai ruang } \\
\text { tunggu yang nyaman }\end{array}$ \\
\hline & \multirow{6}{*}{$\begin{array}{l}\text { Product } \\
\text { Quality }\end{array}$} & Rentang produk & Jasa analisa di PT Sucofindo bervariasi \\
\hline & & Tingkat kualitas & Hasil analisa PT Sucofindo akurat \\
\hline & & Nama merek & Jasa PT Sucofindo ternama / populer \\
\hline & & Lini layanan & $\begin{array}{l}\text { Layanan jasa PT Sucofindo tersebar di } \\
\text { Indonesia }\end{array}$ \\
\hline & & Garansi & $\begin{array}{l}\text { Penggantian sertifikat hasil analisa ketika ada } \\
\text { kesalahan }\end{array}$ \\
\hline & & Dukungan purna beli & $\begin{array}{l}\text { PT Sucofindo bersedia memberikan saran / } \\
\text { masukan terhadap hasil analisa }\end{array}$ \\
\hline \multirow[t]{7}{*}{7} & \multirow[t]{7}{*}{ Price } & Tingkat harga & $\begin{array}{l}\text { Kisaran harga jasa analisa di PT Sucofindo } \\
\text { murah }\end{array}$ \\
\hline & & Diskon & $\begin{array}{l}\text { Potongan harga (diskon) yang ditawarkan PT } \\
\text { Sucofindo menarik }\end{array}$ \\
\hline & & Komisi & $\begin{array}{l}\text { Ada timbal balik yang positif setelah } \\
\text { menggunakan jasa PT Sucofindo }\end{array}$ \\
\hline & & Syarat pembayaran & Cara pembayaran jasa PT Sucofindo fleksibel \\
\hline & & Persepsi konsumen terhadap nilai & Biaya jasa analisa di PT Sucofindo terjangakau \\
\hline & & Kualitas / harga & $\begin{array}{l}\text { Biaya jasa yang ditawarkan PT Sucofindo } \\
\text { sesuai dengan kualitas }\end{array}$ \\
\hline & & Diferensiasi & $\begin{array}{l}\text { Paket harga yang ditawarkan terjangkau / } \\
\text { menarik }\end{array}$ \\
\hline
\end{tabular}

Berdasarkan referensi data atribut yang ada, maka perlu adanya konversi dimana poinpoin pernyataan dibuat berdasarkan konstuk atribut yang ada, sehingga dari pernyataan tersebut dapat dilakukan pengumpulan data seperti yang diinginkan.

\section{Populasi dan Sampel}

Populasi menurut Sugiyono (2012) adalah wilayah generalisasi yang terdiri atas objek/subjek yang mempunyai kualitas dan karakteristik tertentu yang diterapkan oleh peneliti untuk dipelajari dan kemudian ditarik kesimpulannya. Sedangkan secara umum sampel diartikan sebagai bagian dari populasi. Sampel dalam penelitian haruslah bersifat representatif/mewakili agar didapat hasil yang akurat. Adapun penentuan jumlah sampel menurut rumus Slovin adalah sebagai berikut:

$$
n=\frac{\mathrm{N}}{1+\mathrm{N} \propto^{2}}
$$

Dimana: $\mathrm{n}=$ ukuran sampel

$$
\alpha=\text { error }(10 \%)
$$

$\mathrm{N}=$ ukuran populasi
Setelah jumlah sampel ditentukan maka instumen penelitian dibagikan sebagai sumber data, sumber data yang digunakan diantaranya yaitu:

1. Kuesioner

Kuesioner merupakan sejumlah pertanyaan tertulis yang digunakan untuk memperoleh sejumlah informasi dari responden yang berisi laporan tentang pribadinya, atau hal lain yang diketahui. Kuesioner digunakan untuk mengumpulkan data tentang persepsi dan harapan dari konsumen SBU Laboratory Cibitung PT Sucofindo (Persero).

2. Dokumentasi

Dokumentasi adalah pengumpulan data dengan cara mencatat dari dokumen yang telah dimiliki pihak perusahaan. Pengumpulan data dengan dokumentasi akan dilakukan peneliti sejak peneliti berada dilapangan. Dokumentasi tersebut antara lain lokasi, sejarah perusahaan dan perkembangannya. 


\section{Skala Likert}

Sugiyono (2012) menerangkan bahwa skala Likert digunakan untuk mengukur sikap atau pendapat seseorang atau sejumlah kelompok terhadap sebuah fenomena sosial yang dimana jawaban setiap item instrumen mempunyai gradasi dari sangat positif sampai sangat negatif. Dengan skala likert variabel yang akan diukur dijabarkan menjadi indikator variabel. Kemudian indikator tersebut dijadikan titik tolak untuk menyusun item-item instrumen yang dapat berupa pernyataan atau pertanyaan. Berikut adalah skala yang dipakai pada penelitian ini:
a. Tidak Setuju
b. Kurang Setuju
c. Setuju
d. Sangat Setuju

\section{Uji Validitas}

Sebuah instrumen yang akan digunakan dalam penelitian harus dapat mengukur atau mengungkapkan data dari variabel yang diteliti. Hal ini dapat diketahui dengan uji validitas untuk mengetahui valid atau tidaknya sebuah instrumen. Untuk menguji validitas alat ukur, maka terlebih dahulu dihitung harga korelasi dengan rumus Product moment, yaitu:

$r_{x y}=\frac{n \sum x_{i} y_{i}-\left(\sum x_{i}\right)\left(\sum_{y_{i}}\right)}{\sqrt{\left(n \sum x_{i}^{2}-\left(x_{i}\right)^{2}\right)\left(n \sum y_{i}^{2}-\left(y_{i}\right)^{2}\right)}}$

Keterangan:

$\mathrm{r}_{\mathrm{xy}}=$ Koefisien korelasi

$\sum \mathrm{y}=$ Jumlah skor total

$\mathrm{n} \quad=$ Jumlah responden

$\sum \mathrm{x}^{2}=$ Jumlah kuadrat skor item

$\sum \mathrm{y}^{2}=$ Jumlah kuadrat skor total

$\sum \mathrm{x}=$ Jumlah skor item

$\sum x y=$ Total perkalian skor item

Dan total sebuah instrumen dapat dinyatakan valid apabila koefisien korelasinya $\geq 0,3$.

\section{Uji Reliabilitas}

Reliabilitas berbicara mengenai masalah ketepatan (accuracy) alat ukur. Ketepatan ini dapat dinilai dengan analisa statistik untuk mengetahui measurement error atau salah ukur.
Suatu instrumen dikatakan reliabel apabila instrumen tersebut cukup dapat dipercaya sebagai alat pengukur data. Uji reliabilitas pada penelitian ini menggunakan rumus Cronbach's Alpha. Adapun rumus Cronbach's Alpha adalah sebagai berikut:

$r_{11}=\left[\frac{K}{(K-1)}\right]\left[1-\frac{\sum \sigma_{b}^{2}}{\sigma_{\mathrm{t}}^{2}}\right]$

Keterangan:

$\mathrm{r}_{11}=$ Realibilitas instrumen

$\sum \sigma_{\mathrm{b}}{ }^{2}=$ Jumlah varians butir

$\mathrm{K}=$ Banyaknya butir instrumen

$\sum \sigma_{\mathrm{t}}^{2}=$ Varians total

Sugiyono (2010) memberikan penafsiran koefisien korelasi yang didapat tersebut besar atau kecil, adapun tabelnya adalah sebagai berikut:

Tabel 2 Pedoman Interprestasi Terhadap Koefisien Korelasi

\begin{tabular}{cc}
\hline $\begin{array}{c}\text { Interval } \\
\text { Koefisien }\end{array}$ & $\begin{array}{c}\text { Tingkat } \\
\text { Hubungan }\end{array}$ \\
\hline $0,00-0,199$ & Sangat Rendah \\
$0,20-0,399$ & Rendah \\
$0,40-0,599$ & Sedang \\
$0,60-0,799$ & Kuat \\
$0,80-1,000$ & Sangat Kuat \\
\hline
\end{tabular}

6. Importance Performance Analysis (IPA)

Menurut Tjiptono (2011) teknik ini dikemukakan pertama kali oleh Martilla dan James pada tahun 1977 dalam artikel mereka "ImportancePerformance Analysis" yang dipublikasikan di Journal of Marketing. Pada teknik ini, responden diminta untuk menilai tingkat kepentingan dan kinerja perusahaan, kemudian nilai ratarata tingkat kepentingan dan kinerja tersebut dianalisis pada ImportancePerformance Matrix, yang mana sumbu $\mathrm{x}$ mewakili persepsi sedangkan sumbu y mewakili harapan. Maka nanti akan didapat hasil berupa empat kuadran sesuai gambar berikut: 


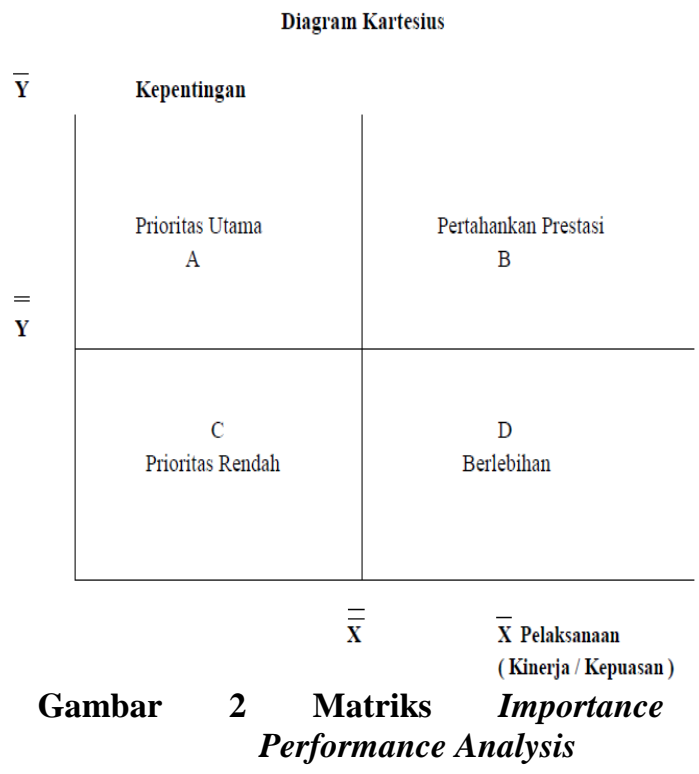

Adapun interpretasi dari kuadran tersebuat adalah sebagai berikut:

A. Prioritas Utama (Concentrate Here)

Pada kuadaran ini terdapat faktorfaktor yang dianggap penting dan atau diharapkan konsumen akan tetapi kinerja perusahaan dinilai belum memuaskan sehingga pihak perusahaan perlu berkonsentrasi untuk mengalokasikan sumber dayanya guna meningkatkan performa yang masuk pada kuadran ini.

B. Pertahankan Prestasi (Keep Up The Good Work)

Pada kuadaran ini terdapat faktorfaktor yang dianggap penting dan diharapkan sebagai faktor penunjang kepuasan konsumen sehingga perusahaan wajib untuk mempertahankan prestasi kinerja tersebut.

C. Prioritas Rendah (Low Priority)

Pada kuadaran ini terdapat faktorfaktor yang dianggap mempunyai tingkat persepsi atau kinerja aktual yang rendah dan tidak terlalu penting dan atau tidak terlalu diharapkan oleh konsumen sehingga perusahaan tidak perlu memprioritaskan atau memberikan perhatian lebih pada faktor-faktor tersebut.

D. Berlebihan (Possibly Overkill) Pada kuadaran ini terdapat faktorfaktor yang dianggap tidak terlalu penting dan tidak terlalu diharapkan oleh pelanggan sehingga perusahaan lebih baik mengalokasikan sumber daya yang terkait pada faktor tersebut kepada factor lain yang lebih memiliki tingkat prioritas lebih tinggi.

\section{DATA DAN ANALISIS}

Dari jumlah populasi yang ada yakni 4790, maka dihitung jumlah sampel yang diperlukan dengan menggunakan rumus Slovin:

$$
\begin{aligned}
& n=\frac{\mathrm{N}}{1+\mathrm{N}^{2} \alpha^{2}} \\
& n=\frac{4790}{1+4790(0,1)^{2}} \\
& n=98 \text { pelanggan } \\
& \text { Secara keseluruhan skor kepuasan } \\
& \text { pelanggan tiap atribut dapat disimpulkan } \\
& \text { sebagai berikut: }
\end{aligned}
$$

\begin{tabular}{|c|c|c|c|c|}
\hline \multirow{2}{*}{ No } & \multirow{2}{*}{ Pernyataan } & \multicolumn{2}{|c|}{ Skor } & \multirow{2}{*}{$\begin{array}{c}\text { Skor } \\
\text { Kepuasan }\end{array}$} \\
\hline & & Persepsi & Ekspektasi & \\
\hline 1 & $\begin{array}{l}\text { Potongan harga (diskon) yang ditawarkan PT Sucofindo } \\
\text { menarik }\end{array}$ & 2.69 & 3.41 & -0.72 \\
\hline 2 & Kisaran harga jasa analisa di PT Sucofindo murah & 2.69 & 3.37 & -0.68 \\
\hline 3 & Paket harga yang ditawarkan terjangkau / menarik & 2.87 & 3.44 & -0.57 \\
\hline 4 & Biaya jasa analisa di PT Sucofindo terjangkau & 2.88 & 3.38 & -0.50 \\
\hline 5 & Hasil analisa PT Sucofindo akurat & 3.08 & 3.50 & -0.42 \\
\hline 6 & $\begin{array}{l}\text { PT Sucofindo menyampaikan jasa sesuai waktu yang } \\
\text { dijanjikan }\end{array}$ & 2.97 & 3.38 & -0.41 \\
\hline 7 & $\begin{array}{l}\text { Biaya jasa yang ditawarkan PT Sucofindo sesuai dengan } \\
\text { kualitas }\end{array}$ & 3.04 & 3.44 & -0.40 \\
\hline 8 & $\begin{array}{l}\text { Karyawan PT Sucofindo memberi perhatian individual } \\
\text { kepada Anda }\end{array}$ & 2.99 & 3.35 & -0.36 \\
\hline 9 & Penggantian sertifikat hasil analisa ketika ada kesalahan & 3.09 & 3.45 & -0.36 \\
\hline
\end{tabular}

Tabel 3 Skor Kepuasan Pelanggan Berdasarkan Peringkat 


\begin{tabular}{|c|c|c|c|c|}
\hline \multirow{2}{*}{ No } & \multirow{2}{*}{ Pernyataan } & \multicolumn{2}{|c|}{ Skor } & \multirow{2}{*}{$\begin{array}{c}\text { Skor } \\
\text { Kepuasan }\end{array}$} \\
\hline & & Persepsi & Ekspektasi & \\
\hline 10 & Pelayanan customer service PT Sucofindo cepat & 3.02 & 3.37 & -0.35 \\
\hline 11 & $\begin{array}{l}\text { PT Sucofindo bersedia memberikan saran / masukan } \\
\text { terhadap hasil analisa }\end{array}$ & 3.06 & 3.41 & -0.35 \\
\hline 12 & $\begin{array}{l}\text { Karyawan PT Sucofindo memberi kepastian waktu } \\
\text { penyelesaian jasa }\end{array}$ & 3.04 & 3.38 & -0.34 \\
\hline 13 & Karyawan PT Sucofindo menumbuhkan rasa percaya Anda & 3.07 & 3.41 & -0.34 \\
\hline 14 & $\begin{array}{l}\text { Karyawan PT Sucofindo mengutamakan kepentingan } \\
\text { kepentingan Anda }\end{array}$ & 3.08 & 3.41 & -0.33 \\
\hline 15 & $\begin{array}{l}\text { Ada timbal balik yang positif setelah menggunakan jasa PT } \\
\text { Sucofindo }\end{array}$ & 3.04 & 3.37 & -0.33 \\
\hline 16 & $\begin{array}{l}\text { Syarat pembayaran jasa PT Sucofindo dijelaskan dengan } \\
\text { baik }\end{array}$ & 3.09 & 3.41 & -0.32 \\
\hline 17 & Sertifikat hasil analisa jelas / tanpa kesalahan & 3.13 & 3.44 & -0.31 \\
\hline 18 & Layanan jasa PT Sucofindo tersebar di Indonesia & 3.13 & 3.44 & -0.31 \\
\hline 19 & PT Sucofindo bersedia membantu Anda & 3.15 & 3.45 & -0.30 \\
\hline 20 & $\begin{array}{l}\text { PT Sucofindo mempunyai respon yang baik ketika ada } \\
\text { permintaan pelanggan mengenai kebutuhan jasa }\end{array}$ & 3.17 & 3.47 & -0.30 \\
\hline 21 & PT Sucofindo menyediakan jasa sesuai yang dijanjikan & 3.08 & 3.37 & -0.29 \\
\hline 22 & Jasa analisa di PT Sucofindo bervariasi & 3.15 & 3.44 & -0.29 \\
\hline 23 & $\begin{array}{l}\text { Karyawan PT Sucofindo menyediakan jasa yang dapat } \\
\text { menangani masalah Anda }\end{array}$ & 3.10 & 3.37 & -0.27 \\
\hline 24 & Sistem transaksi jasa PT Sucofindo berjalan dengan baik & 3.13 & 3.40 & -0.27 \\
\hline 25 & $\begin{array}{l}\text { Karyawan PT Sucofindo menyampaikan jasa secara benar } \\
\text { sejak awal menggunakan jasa }\end{array}$ & 3.14 & 3.40 & -0.26 \\
\hline 26 & $\begin{array}{l}\text { Karyawan PT Sucofindo mampu menjawab pertanyaan } \\
\text { pelanggan seputar jasa yang ditawarkan }\end{array}$ & 3.10 & 3.34 & -0.24 \\
\hline 27 & $\begin{array}{l}\text { Karyawan PT Sucofindo memperlakukan Anda dengan } \\
\text { penuh perhatian }\end{array}$ & 3.13 & 3.37 & -0.24 \\
\hline 28 & Karyawan PT Sucofindo memahami kebutuhan Anda & 3.12 & 3.35 & -0.23 \\
\hline 29 & PT Sucofindo mempunyai waktu beroperasi yang baik & 3.13 & 3.36 & -0.23 \\
\hline 30 & $\begin{array}{l}\text { PT Sucofindo (Persero) mempunyai ruang tunggu yang } \\
\text { nyaman }\end{array}$ & 3.22 & 3.45 & -0.23 \\
\hline 31 & Jasa PT Sucofindo ternama / populer & 3.20 & 3.43 & -0.23 \\
\hline 32 & Peralatan yang digunakan PT Sucofindo modern & 3.19 & 3.40 & -0.21 \\
\hline 33 & Karyawan PT Sucofindo melayani dengan baik & 3.22 & 3.40 & -0.18 \\
\hline 34 & Fasilitas gedung PT Sucofindo rapi / bersih & 3.28 & 3.46 & -0.18 \\
\hline 35 & $\begin{array}{l}\text { Karyawan PT Sucofindo berpenampilan rapi dan } \\
\text { professional }\end{array}$ & 3.24 & 3.42 & -0.18 \\
\hline
\end{tabular}

Berdasarkan tabel diatas, maka dapat diketahui bahwa semua atribut memiliki nilai negatif yang berarti bahwa setiap atribut tersebut belum memenuhi harapan pelanggan. Dari data tersebut maka perlu analisis lebih lanjut untuk menentukan skala prioritas dalam usaha perbaikan dari setiap atribut yang ada, adapun cara untuk menentukan skala prioritas pembenahan yang ada adalah dengan menggunakan metode Importance Performance Analysis (IPA).

\section{ANALISIS \\ IMPORTANCE PERFORMANCE ANALYSIS (IPA)}

Pada bagian ini dibahas mengenai pemetaan dari nilai kinerja $(\mathrm{x})$ dan harapan (y), dari hasil tersebut maka akan terbentuk matriks yang terdiri dari empat buah kuadran yang masing-masing kuadran menggambarkan skala prioritas dalam mengambil kebijakan baik berupa peningkatan kinerja atau mempertahankan kinerja perusahaan. Berikut adalah data sebaran kinerja dan harapan pelanggan: 


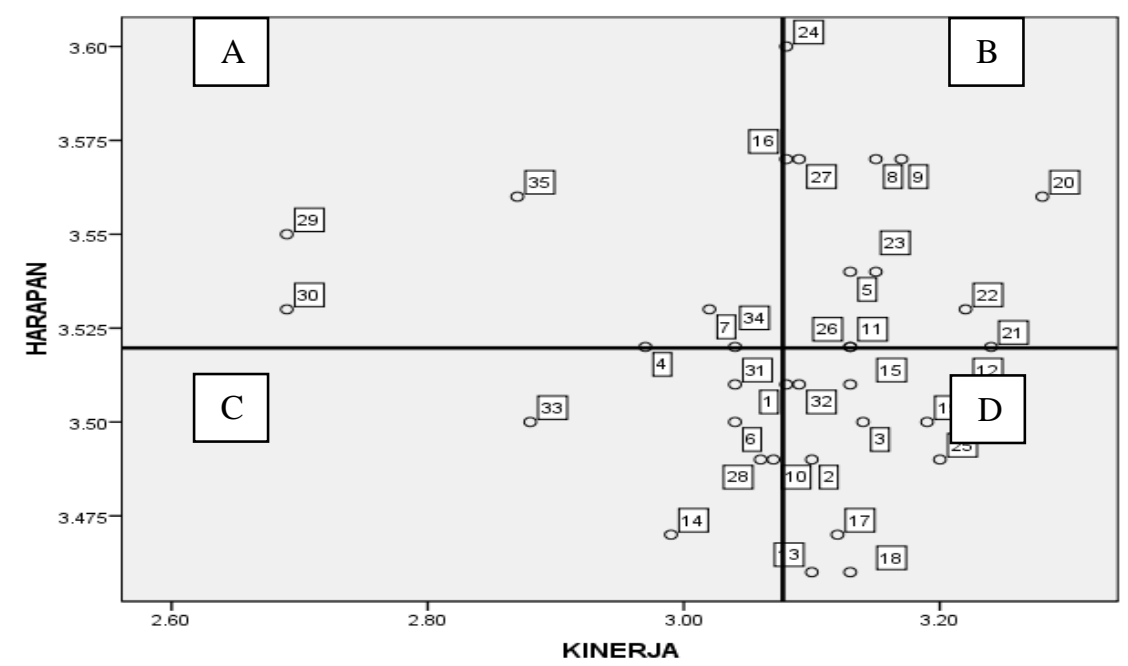

Gambar 3 Diagram Kartesius Pengukuran Kepuasan Pelanggan

Dari gambar tersebut maka dapat diinterpretasikan sebagai berikut:

1. Kuadran A

Kuadran A menunjukkan faktor atau atribut yang dianggap penting oleh pelanggan namun tidak terlaksanakan dengan baik oleh perusahaan. Variabelvariabel yang termasuk dalam kuadran ini adalah:

(7) Pelayanan customer service PT Sucofindo cepat

(29) Kisaran harga jasa analisa di PT Sucofindo murah

(30) Potongan harga (diskon) yang ditawarkan PT Sucofindo menarik

(34) Biaya jasa yang ditawarkan PT Sucofindo sesuai dengan kualitas

(35) Paket harga yang ditawarkan terjangkau / menarik

Dengan demikian item-item tersebut menjadi skala prioritas utama perusahaan untuk diperbaiki.

2. Kuadran B

Kuadran B menunjukkan faktor atau atribut yang dianggap penting dan memuaskan pelanggan yang sudah dilaksanakan dengan baik oleh perusahaan. Variabel-variabel yang termasuk dalam kuadran ini adalah:

(5) Sertifikat hasil analisa jelas / tanpa kesalahan

(8) PT Sucofindo bersedia membantu pelanggan
(9) PT Sucofindo mempunyai respon yang baik ketika ada permintaan pelanggan mengenai kebutuhan jasa

(11) Sistem transaksi jasa PT Sucofindo berjalan dengan baik

(16) Karyawan PT Sucofindo mengutamakan kepentingan kepentingan pelanggan

(20) Fasilitas gedung PT Sucofindo rapi / bersih

(21) Karyawan PT Sucofindo berpenampilan rapi dan professional

(22) PT Sucofindo (Persero) mempunyai ruang tunggu yang nyaman

(23) Jasa analisa di PT Sucofindo bervariasi

(24) Hasil analisa PT Sucofindo akurat

(26) Layanan jasa PT Sucofindo tersebar di Indonesia

(27) Penggantian sertifikat hasil analisa ketika ada kesalahan

Dengan demikian item-item tersebut perlu dipertahankan kinerjanya oleh pihak perusahaan.

3. Kuadran C

Kuadran $\mathrm{C}$ menunjukkan faktor yang dianggap kurang penting oleh pelanggan dan tidak terlaksanakan dengan baik oleh perusahaan. Variabel-variabel yang termasuk dalam kuadran ini adalah:

(1) PT Sucofindo menyediakan jasa sesuai yang dijanjikan 
(4) PT Sucofindo menyampaikan jasa sesuai deadline / waktu yang dijanjikan

(6) Karyawan PT Sucofindo menyampaikan kepastian watu deadline / penyampaian jasa

(10) Karyawan PT Sucofindo menumbuhkan rasa percaya para pelanggan

(14) Karyawan PT Sucofindo memberi perhatian individual kepada para pelanggan

(28) PT Sucofindo bersedia memberikan saran / masukan terhadap hasil analisa

(31) Ada timbal balik yang positif setelah menggunakan jasa PT Sucofindo

(33) Biaya jasa analisa di PT Sucofindo terjangkau

Dengan demikian item-item diatas dapat diabaikan/mempunyai skala prioritas pembenahan bagi perusahaan

4. Kuadran D

Kuadran D menunjukkan faktor atau atribut yang dianggap kurang penting oleh perusahaan namun dilaksanakan dengan berlebihan oleh perusahaan. Variabel-variabel yang termasuk dalam kuadran ini adalah:

(2) Karyawan PT Sucofindo menyediakan jasa yang dapat menangani masalah pelanggan

(3) Karyawan PT Sucofindo menyampaikan jasa secara benar sejak pertama kali

(12) Karyawan PT Sucofindo bersikap sopan

(13) Karyawan PT Sucofindo mampu menjawab pertanyaan pelanggan seputar jasa yang ditawarkan

(15) Karyawan PT Sucofindo memperlakukan pelanggan dengan penuh perhatian

(17) Karyawan PT Sucofindo memahami kebutuhan pelanggan

(18) PT Sucofindo mempunyai waktu beroperasi yang baik

(19) Peralatan yang digunakan PT Sucofindo modern

(25) Jasa PT Sucofindo ternama / populer
(32) Cara pembayaran jasa PT Sucofindo fleksibel

Dengan demikian item-item tersebut berlebihan dilaksanakan oleh perusahaan, untuk itu lebih baik pihak perusahaan mengalokasikan sumber dayanya untuk prioritas utama terlebih dahulu.

\section{KESIMPULAN}

Berdasarkan hasil perhitungan skor kepuasan pelanggan yang telah dilakukan yang meliputi variabel reliability, responsiveness, assurance, empathy, tangible, product quality, dan price dapat diketahui tiga item terbaik yaitu: Karyawan PT Sucofindo berpenampilan rapi dan professional, Fasilitas gedung PT Sucofindo rapi / bersih, dan Karyawan PT Sucofindo melayani dengan baik

Dengan analisis Importance Performance Analysis (IPA) maka dapat diketahui masih terdapat 13 hal yang harus ditingkatkan kedepannya. Akan tetapi masih ada kesalahan yang disebabkan oleh pelanggan misalnya keterlambatan pengiriman sampel, keterlambatan pembayaran, kesalahan pengisian identitas dsb yang menyebabkan keterhambatan pengerjaan.

\section{DAFTAR PUSTAKA}

1. Herjanto, Eddy. (2008). Manajemen Operasi. Jakarta: Grasindo.

2. Sugiyono, Prof., Dr. (2010). Statistika Untuk Penelitian. Bandung : Alfabeta, CV

3. Sugiyono, Prof., Dr. (2012). Metode Penelitian Kuantitatif Kualitatif dan $R \& D$. Bandung: Alfabeta, $\mathrm{CV}$

4. Suliyanto. (2005). Analisis Data Dalam Aplikasi Pemasaran. Bogor: Ghalia Indonesia.

5. Suliyanto, Dr. (2010). Studi Kelayakan Bisnis. Yogyakarta: Andi.

6. Supranto, J. (2010). Analisis Multivariat: Arti dan Interpretasi. Jakarta: Rineka Cipta.

7. Tjiptono, Fandy., Gregorius Chandra. (2011). Service, Quality, \& Satisfaction, Edisi 3 Yogyakarta: Andi. 
8. Umar, Husein. (1997). Metodologi Penelitian: Aplikasi Dalam Pemasaran. Jakarta: PT Gramedia Pustaka Utama.

9. Uyanto, Stanislaus S, Ph.D. (2009). Pedoman Analisis Data Dengan SPSS. Yogyakarta: Griya Ilmu.
10.Zeithaml, Valarie A., And Mary Jo Bitner. (2000). Service Marketing: Integrating Customer Focus Across The Firm, Second Edition. New York, NJ: Mc Graw-Hill Companies Inc. 